\title{
Bacterial and Chemical Contamination Associated Carpet Dust in the Holy Mosque, Makkah Al-Mukarramah
}

\author{
Bassam Husain Mashat \\ Department of Environmental and Health Research, the Custodian of the Two Holy Mosques \\ Institute for Hajj Research, Umm Al-Qura University, Makkah Al-Mukarramah, P.O. 6287, Saudi \\ Arabia
}

\begin{abstract}
Carpets are widely used as surface covering in the holy mosque (Almasjed Alharam) settings, and they are prone to contamination with infectious agents and chemical components. This study aims to evaluate the concentrations of bacteria and chemical pollutants associated carpet dust in the holy mosque, as well as bacterial concentrations in the air state. The dust samples were collected from eighty carpets during month of Ramadan 2011, using a cord portable vacuum cleaner. Airborne bacteria were collected using Airport MD8 gelatin filter sampler. Bacterial concentrations varied depending on location of carpets inside the mosque, with no significant differences between locations $(\mathrm{P} \geq 0.05)$. The highest mean bacterial concentrations associated dust $\left(256.42 \times 10^{6} \mathrm{CFU} / \mathrm{m}^{2}\right)$ and in the air state $\left(1.12 \times 10^{5} \mathrm{CFU} / \mathrm{m}^{3}\right)$ were found at the ground floor of 1st expansion location. The highest re-suspension factor (RF) was found at the ground floor of 1 st expansion, and the lowest at ground floor of 2nd expansion. Bacillus (25\%), Pseudomonas (13\%) and Micrococcus $(12 \%)$ were the dominated bacterial genera. Chloride and ammonium concentrations associated dust were higher at the basement and the ground floor locations. The results did not indicate the presence of any apparent seriousness of the current situation of the carpets in the holy mosque. The data can be treated as a first step in determining the acceptable levels for microorganisms associated carpets in the common indoor environments.
\end{abstract}

Keywords: the holy mosque, carpet, dust, bacteria, chemical components, risk assessment.

\section{Introduction}

Indoor environment is a unique and is characterized by its own sources. The holy mosque is furnished with the finest carpets, and their number is $\sim 30,000$ with various sizes. The carpet is considered a good environment for the growth of microorganisms, if appropriate temperature and humidity are available. The carpet works on absorption and book dust. Simply by walking across a floor, carpet or other flooring materials, microbes can become airborne, which can cause non-infectious airway diseases, allergies, asthma, or serious infectious (Miller and Colemans, 2015).

Studies have demonstrated that, in addition to particles suspended in outdoor air, material resuspended from surfaces, as a result of human activities, is an important source of indoor airborne particles. Relationships have been found between indoor airborne microbial contents and those-associated carpets (Bholah and Subratty, 2002; Gehring, et al, 2002, Ferro, et al., 2004; Bouillard, et al, 2005). Carpets and sofas represented a huge reservoir of mites, and allergens (Custovic, et al., 2002), 
however other investigators found no relationships between carpets and microbial contents (Dotterud, et al., 1995; Hargreaves, et al., 2003).

Microorganisms usually enter buildings through outdoors or intake of air conditioning systems, human activities, and contaminated building materials (Hansen, 1999; Bowers, et al., 2012; Kembel, et al., 2012). Fungi can colonize walls, windows, frames, dump furniture, and carpets (Stepalska, et al., 1999; Khan and Karuppayil, 2012). Comparing biocontamination of tiled floor and carpeted one, the carpeted surfaces being strong sinks and had higher surface loading of microorganisms, and airborne microbial levels were higher over the tiled floor (Foarde and Berry, 2004). In contrast fungal and bacterial concentrations in the air above carpets were consistently higher than those over-non carpeted floors (Gravesen, et al., 1983). Fungal and bacterial infections are transmitted by direct contact with infected persons, soils, skin and hair (Dahdah and Scher, 2008). Dermatophytes were isolated from house dust of patients, residence (Sugimoto et al., 1995), socks (Katoh, 2006), slippers (Goksugur, et al., 2006), communal ablution areas and prayer carpets of the mosques (Raboobee, et al., 1998, Yenisehirli, et al., 2012).

Millions of musilm people visit Makkah every year and they prefer performing all prayers (five times each day) in Almasjed Alharam. The floor of Almasjed Alharam is entirely covered with carpets to cushion the knees and heads during worship. People takeoff their shoes before entering the Al-Haram and directly step on the carpets. The carpets may be possibly contaminated with normal and infectious microorganisms. Little research works have been done on the presence of microorganisms associated carpets. Therefore, the present study aims to determine bacterial and chemical component $\left(\mathrm{SO}^{2-}, \mathrm{PO}^{3-}, \mathrm{NO}^{-}\right.$, $\left.\mathrm{Cl}^{-}, \mathrm{CO}^{2-}\right)$ concentrations associated the carpet dust, and bacterial concentrations in the air at different locations in the holy mosque, as well as to discuss some solutions of reducing contamination of the carpet.

\section{Materials and Methods}

\section{Sampling locations and strategy}

A total of 240 dust associated carpet, and 80 airborne bacterial samples were collected at six locations inside and outside the holy mosque (Table 1). The sampling locations represented the different micro-environment and human activity inside the holy mosque. Air samples were collected at a height of 1.5 $\mathrm{m}$, the breathing zone, above the floor level. The both dust associated carpet and air samples were taken between 4.00 p.m and 9.00 p.m, during the month of Ramadan 1432 H (129 August- 2011).

\section{Chemical components associated settled dust sampling}

Dust associated carpets were collected using cord portable vacuum cleaner ((Model Sanyo, 2000W, Japan), by sampling the carpet area of $1 \mathrm{~m} 2$ during $3 \mathrm{~min}$. After sampling, 100 $\mathrm{mg}$ of the collected dust was dissolved in 100 $\mathrm{ml}$ distilled water, and shaken well for $\sim 30-60$ min at the room temperature. The solution was filtrated through Whatman filter paper No-42, and the concentrations of $\mathrm{SO}^{2-}, \mathrm{PO}^{2-}, \mathrm{NO}^{3-}$, $\mathrm{Cl}^{-}, \mathrm{NH}_{4}^{+}$were determined in the water fraction (Harrison and Perry, 1986). The concentrations of chemical components were expressed as $\mu \mathrm{g} / \mathrm{g}$ of dust.

\section{Airborne bacteria and bacteria associated settled dust sampling}

The bacteria associated carpet dust was collected by using a vacuum pump, and sampling an area of $100 \mathrm{~cm}^{2}$ of the carpet, during $1 \mathrm{~min}$ (Fig 1). The samples were collected from three parts of the carpet: 1) the place of prostration (upper part), 2) the center of the carpet, and 3) the lower part (place of feet). The dust particles were separately 
aspirated into a washing bottle containing 25 $\mathrm{ml}$ sterilized buffer phosphate .

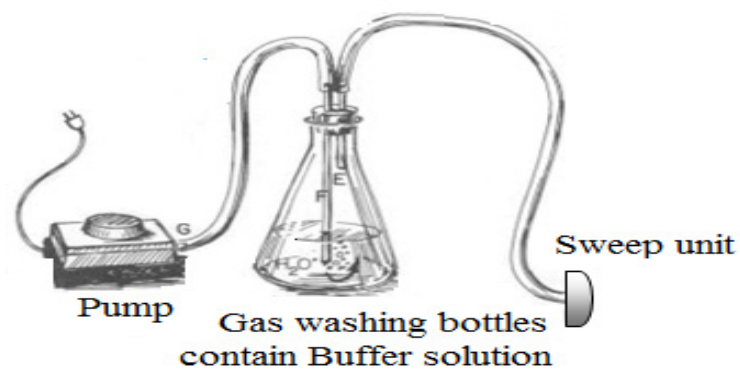

Fig.1. Illustrated device is used in microbiological accumulating samples from carpets.

Airborne bacteria were sampled using Airport MD8 gelatin filter sampler (Sartorius AG, Göttingen, Germany). The sampler was equipped with a flexible plastic hose connected with a filter head containing an 80$\mathrm{mm}$ diameter gelatin membrane filter (Sartorius Stedim Biotech GmbH, Göttingen, Germany). The air sampler was operated at a flow rate of $50 \mathrm{1} / \mathrm{min}$, for $30 \mathrm{~min}$. After sampling, filters were dissolved in $25 \mathrm{ml}$ of phosphate-buffered saline, and shaken well in the room temperature, for $10 \mathrm{~min}$.

Serial dilutions up to 105 were prepared and aliquots $(0.5 \mathrm{ml})$ of the buffer phosphate and its serial dilutions were spread-plated onto the surface of nutrient agar medium to determine bacterial concentration. The bacterial plates were incubated at $37^{\circ} \mathrm{C}$ for 48 $\mathrm{h}$. The growing colonies were counted and the mean count was calculated. The concentrations were expressed as colony forming units per $\mathrm{m}^{2}$ $\left(\mathrm{CFU} / \mathrm{m}^{2}\right)$, and colony forming unit per cubic meter of air $\left(\mathrm{CFU} / \mathrm{m}^{3}\right)$ for bacteria associated carpet dust and airborne bacteria, respectively.

\section{Re-suspension factor (RF)}

The airborne bacterial concentration of a finely particle contaminant can be related to its removable surface concentration via the resuspension factor equation:
RF $\left(\mathrm{m}^{-1}\right)=$ airborne concentration $\mathrm{CFU} / \mathrm{m}^{3} /$ Surface concentration $\mathrm{CFU} / \mathrm{m}^{2}$

The resuspension factor depends on the nature of the contaminant, the environment, and the activity taking place. The resuspension factor of air bacterial contamination is necessary for estimating the degree of contamination due to resuspension of surface/ carpet associated bacteria during maintenance and cleaning activities inside the holy mosque.

\section{Identification of bacteria}

Three to five bacterial isolates differed in morphology which appear in more than $5 \%$ of the nutrient agar medium were picked up, purified and subcultured for further identification. The bacterial isolates were identified using Gram stain, oxidation fermentation, oxidase and catalase tests as described in the Bergey's Manual of Systematic Bacteriology (Sneath, et al., 2000).

\section{Risk assessment}

Programs and mathematical equations were used in order to calculate the risks resulting from exposure to these compounds, and also the daily and age dose calculation, risk of cancer and as well as risk coefficient (Hassanien, et al., 2009).

\section{Statistical Analysis}

Data were statistically analyzed by one way analysis of variance test (One Way ANOVA) to find the difference between the means of bacterial counts associated carpets and their sampling sites inside the holy Mosque. $\mathrm{P} \leq$ 0.05 was considered as significant.

\section{Results and Discussion}

Microorganisms associated carpets are considered one source of bio-pollution in the closed spaces. Different studies have tended to identify the materials and factors that affecting bio-pollution and evaluating the control methods that can be efficiently reduced or eliminated bio-pollutants. 
The range and the mean concentrations of bacteria associated carpets and in the air state are shown in Table 1. The concentrations of bacteria associated carpets ranged between $76 \times 10^{4}-572 \times 10^{6} \mathrm{CFU} / \mathrm{m}^{2}$ at the roof surface and $96 \times 10^{4}-649.6 \times 10^{6} \mathrm{CFU} / \mathrm{m}^{2}$ at different sampling locations inside $\mathrm{Al}$ haram. The highest mean bacterial concentration $\left(256.42 \times 10^{6} \mathrm{CFU} / \mathrm{m}^{2}\right)$ was found at the ground floor of $1^{\text {st }}$ expansion, however the lowest $(910$ $\mathrm{x} 10^{5} \mathrm{CFU} / \mathrm{m}^{2}$ ) was found at the roof surface, as roof surfaces' carpets are exposed sun ray's heat and natural wind. Inside Al Haram, the lowest bacterial concentration associated carpets was found in the basement location, because lower number of people perform worship in the basement place. In the present study, significant differences $(P \leq 0.05)$ were found between bacterial concentrations associated carpets at the roof surface and basement with those associated carpets inside the mosque. On the other hand no significant differences $(P \geq 0.05)$ were found between bacterial concentrations associated carpets at the ground floor and the first floor.

The bacterial concentrations vary regarding location. This may be related to the number of people and their activities, and ventilation rate. Microbial concentrations depend on many variables such as anthropogenic influence, human activity, topography, microenvironmental conditions, and type of sources (Després, et al., 2012). The influence of irregular disturbances and human activities lead to high microbial variations. Microorganisms are found/deposited on the floor surfaces through a variety of methods including foot traffic, food and drink spills, and bodily fluid deposition. Some microorganisms found on floors and in carpet can be re-suspended again into the air, and transported and settled on other locations in the closed spaces (Leonas, 2003).

In the present study, airborne bacterial concentrations ranged between $9 \times 10^{2}-1.32 \times 10^{5}$
$\mathrm{CFU} / \mathrm{m}^{3}$ (Table 1). The highest mean airborne bacterial concentration $\left(1.12 \times 10^{5} \mathrm{CFU} / \mathrm{m}^{3}\right)$ was found at the ground floor of $1^{\text {st }}$ expansion and the lowest $\left(1.31 \times 10^{3} \mathrm{CFU} / \mathrm{m}^{3}\right)$ at the ground floor of $2^{\text {nd }}$ expansion. This confirms the presence of a relationship between airborne microbial contents and those associated carpet dust, because carpets are one of the microbial sources in indoor air environment (Bouillard, et al., 2005; Ramachandran, et al., 2005).

Carpet can absorbs and reserves dust, and this phenomenon is growing in the holy mosque, due to the extensive demolition and renovation nearby the mosque. The carpet itself is a good environment for the growth of microbes, if suitable conditions are available" temperature, humidity and moisture". Almost $15 \%$ of bacterial types in the indoor air are carried and transmitted from the contaminated floors through human activities" walking, wiping and cleaning (Hambraeus, et al., 1978). The carpet is considered one source of indoor air pollution in schools and hospitals, however the quality of the materials and cleaning help reduce the probability of indoor air pollution (Meckel, 1982). Anderson, et al. (1982) reported that the microbial content in patients' rooms furnished carpeted was higher than the microbial content of the unfurnished carpeted rooms.

In the present study, the highest resuspension factor (RF) was found at the ground floor of $1^{\text {st }}$ expansion, and the lowest at ground floor of $2^{\text {nd }}$ expansion (Table 1). The term resuspension is mainly used to describe the process by which any aerial deposited materials might become airborne. The resuspension can be of concern because the possibility of spreading human diseases and contamination in indoor environment (Aylor, 1976; Nicholson, 1995). In the present study, it is clear that inhalation dose may be higher at the ground floor of $1^{\text {st }}$ expansion, which may be uncomfortable area for people inside the holy mosque. 
Table 1. The range and mean concentrations of bacteria-associated carpet dust and airborne bacteria regarding location at Al Haram

\begin{tabular}{|c|c|c|c|c|c|}
\hline \multirow[t]{2}{*}{ Location } & \multicolumn{2}{|c|}{ Bacteria associated carpet dust } & \multicolumn{2}{|c|}{ Airborne bacteria } & \multirow[t]{2}{*}{$\mathrm{FR}\left(\mathrm{m}^{-1}\right)$} \\
\hline & No. & $\mathrm{CFU} / \mathrm{m}^{2} \times 10^{4}$ & No. & $\mathrm{CFU} / \mathrm{m}^{3} \times 10^{3}$ & \\
\hline Basement & & $\begin{array}{c}(96-49550) \\
{[13831.1]}\end{array}$ & 15 & $\begin{array}{c}(48-58) \\
{[53.2]}\end{array}$ & 0.00038 \\
\hline Ground floor of $2^{\text {nd }}$ expansion & 30 & $\begin{array}{c}(1159-64865) \\
{[21485.2]}\end{array}$ & 15 & $\begin{array}{c}(0.9-2) \\
{[1.31]}\end{array}$ & 0.0000061 \\
\hline Ground floor of $1^{\text {st }}$ expansion & 30 & $\begin{array}{c}(578-60060) \\
{[25642.2]}\end{array}$ & 15 & $\begin{array}{c}(96-132) \\
{[112.4]}\end{array}$ & 0.00044 \\
\hline $1^{\text {st }}$ floor of $2^{\text {nd }}$ expansion & 30 & $\begin{array}{c}(531-59676) \\
{[18890.4]}\end{array}$ & 15 & $\begin{array}{c}(63-72) \\
{[67.8]}\end{array}$ & 0.00036 \\
\hline $1^{\text {st }}$ floor of $1^{\text {st }}$ expansion & 27 & $\begin{array}{c}(570-55255) \\
{[22556.6]} \\
\end{array}$ & 15 & $\begin{array}{c}(35-58) \\
{[46.3]}\end{array}$ & 0.00021 \\
\hline The roof surface of Al-Haram & 63 & $\begin{array}{c}(76-57200) \\
{[9104.6]}\end{array}$ & 15 & $\begin{array}{c}(76-97) \\
{[84.6]}\end{array}$ & 0.00093 \\
\hline
\end{tabular}

No: number of collected samples, $\mathrm{RF}\left(\mathrm{m}^{-1}\right)$ : resuspension factor.

Figure 2 shows the mean concentrations of bacteria-associated dust regarding the part of the carpet. The concentrations ranged between $96 \times 10^{4}-64865 \times 10^{4} \mathrm{CFU} / \mathrm{m}^{2}$. The highest concentration $\left(18.459 \times 10^{7} \mathrm{cfu} / \mathrm{m}^{2}\right)$ was found in the lower part of the carpet (place of feet), with no significant differences with concentrations in the other parts of the carpet. This is attributed to during prayer; feet contact the carpets more longer time than other parts of the body. A carpet has some similarity to an air filter that the dirt particles can become mechanically trapped, and not easily dislodged during cleaning, and the particles adhesion is increased if the carpet is moist and if both particle and the carpet fiber are wetted (Pope, et al., 1993).

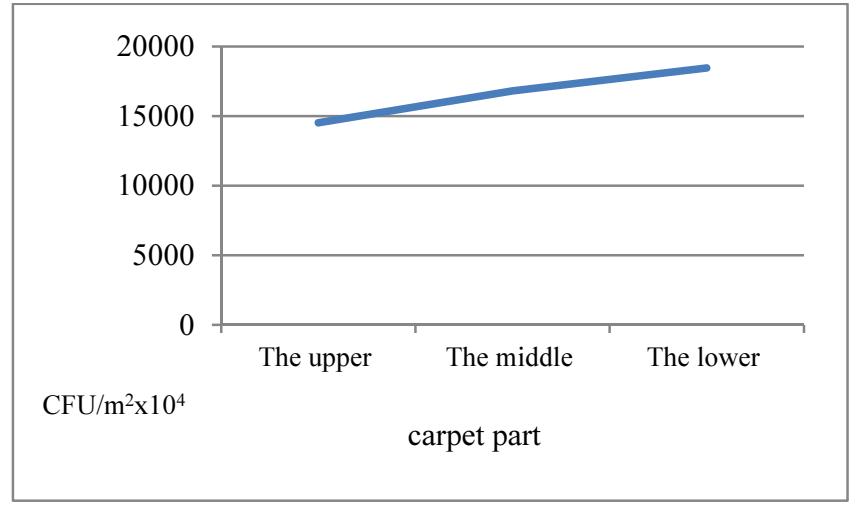

Fig. 2. The mean concentrations of bacteria associated dust regarding the part of the carpet.

In the present study, Bacillus sp, B. subtilis, B. circulans, Escherichia coli, Klebsiella sp., K. pneumonia, Micrococcus sp., M. roseus, Peptostreptococcus sp., Pseudomonas sp., P. aeruginosa, Proteus sp., Ruminococcus sp., Staphylococcus sp., S. aureus, Streptococcus sp. were isolated. Bacillus $(25 \%)$, Pseudomonas (13\%) and Micrococcus (12\%) were the dominated genera associated carpets. The genera associated carpet samples were similar with those genera isolated from the indoor air of the Holy Mosque (Nasrallah, et al., 2007). This confirms the existence of a relationship between bacterial content of the 
internal air and those in the carpet, and the resuspension has a significant role in the airborne bacterial content.

The concentrations of chemical components of the dust associated carpets at different sampling sites are shown in figure 3. The chemical component concentrations varied regarding sampling site. Sulfates, phosphates and nitrates concentrations were lower at the roof surface and the ground floor than those found in the basement and the first floor. This is attributed to the amount of outdoor dust particles infiltrate to indoors. The outdoor dust particles are mainly emitted from traffic and renovation activities around the holly mosque. On the other hand, chloride and ammonium concentrations were higher at the basement and the ground floor due to the use of detergents and lack of air ventilation.

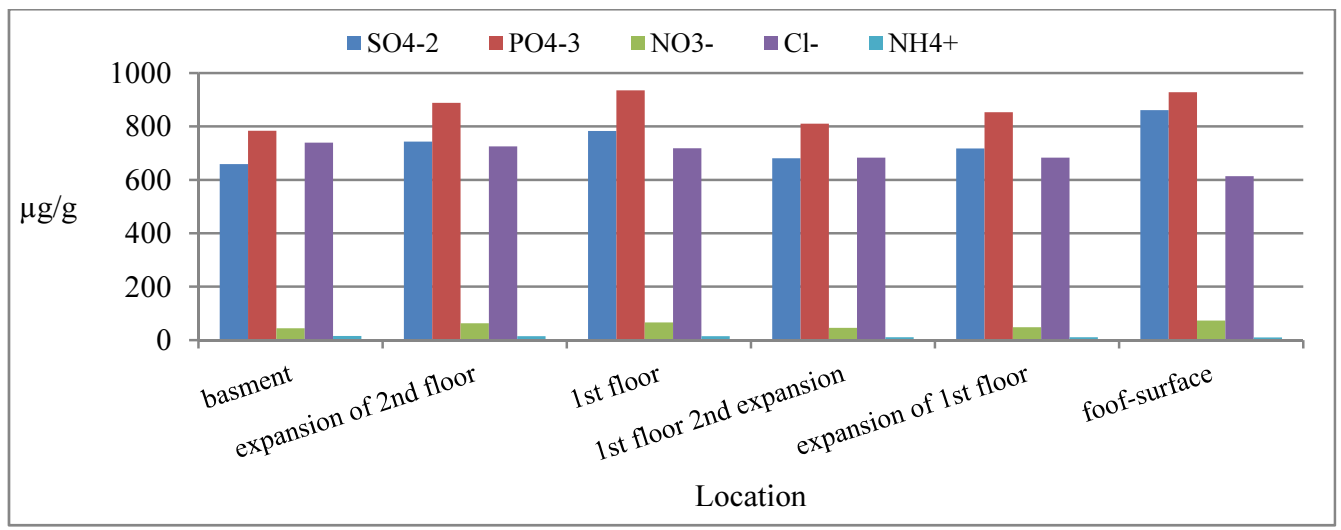

Fig.3. The mean concentrations of chemical components of dust associated carpets

The present study focuses on calculating risk coefficient that is occurred as a result of human exposure to chemical components, regarding daily and age dose, danger of cancer, coefficient of Hazard Quotient (H.Q), and the contribution of these chemical concentrations in the air (Table 2). The results showed that there was no cancer risk, and the H.Q represented little value $\left(\sim 4 \times 10^{-6}\right)$, "if H.Q $\leq 1$, it means that no human risk due to exposure to the carpets' dust and its chemical components'(Hassanein, et al., 2009).
The visitors of the holy mosque who exposed to such chemical concentrations did not represent any unexpected dangerous under any other expectations. Due to the lack of specifications/or limits that are recognized by the quality and quantity of microbial and chemical contents associated carpets, the obtained results did not indicate the presence of any apparent seriousness of the current situation of the carpets in the holy mosque.

Table 2. The expected chemical component concentrations in the air, daily and age dose, risk coefficient and danger of cancer.

\begin{tabular}{|c|c|c|c|c|c|}
\hline \multirow{2}{*}{ Substance } & \multicolumn{2}{|c|}{ Daily dose } & \multicolumn{2}{|c|}{ Age dose } & \multirow{2}{*}{$\begin{array}{l}\text { Expected conc. } \\
\text { in the air } \\
\left(\mu \mathrm{g} / \mathrm{m}^{3}\right)\end{array}$} \\
\hline & $\begin{array}{l}\text { Exposure } \\
\left(\mathrm{mg} / \mathrm{m}^{3}\right)\end{array}$ & $\begin{array}{l}\text { Swallowing } \\
\text { (mg/kg/day) }\end{array}$ & $\begin{array}{l}\text { Exposure } \\
\left(\mathrm{mg} / \mathrm{m}^{3}\right)\end{array}$ & $\begin{array}{l}\text { Swallowing } \\
\text { (mg/kg/day) }\end{array}$ & \\
\hline Nitrate & $2 \times 10^{-6}$ & $7 \times 10^{-6}$ & $2 \times 10^{-7}$ & $10^{-8}$ & $2 \times 10^{-6}$ \\
\hline Sulphate & $3 \times 10^{-5}$ & $8 \times 10^{-5}$ & $2 \times 10^{-6}$ & $10^{-6}$ & $3 \times 10^{-5}$ \\
\hline Chloride & $2 \times 10^{-5}$ & $7 \times 10^{-5}$ & $2 \times 10^{-6}$ & $10^{-6}$ & $2 \times 10^{-5}$ \\
\hline Ammonium & $4 \times 10^{-7}$ & $1 \times 10^{-6}$ & $2 \times 10^{-8}$ & $2 \times 10^{-8}$ & $4 \times 10^{-7}$ \\
\hline
\end{tabular}

Sum of risk coefficient of all components $=4 \times 10^{-6}$ 


\section{Decontamination of the carpets}

The carpet cleaning machine reduced the number of Salmonella enterica but could not completely get rid of this strain (Rice et al., 2003). Hydrogen peroxide gas reduced concentrations of B. anthracis, B. subtilis, and Geobacillus stearothermophilus associated carpets (Rogers et al., 2007). Malik et al. (2006) got rid of Feline calicivirus in the contaminated carpet and upholstery by using disinfectant of Metricide and Microbac-II within a minute to 10 minutes, but the eliminated rate of the virus decreased in furnishings manufactured of $100 \%$ polyester. Recently some carpet manufacturers have treated their products with fungicidal and/or bactericidal chemicals that help reduce the overall numbers of bacteria or fungi and their use do not preclude the routine care and maintenance of the carpeting (CRI, 2013).

\section{Conclusions}

Carpets are considered one of the important indoor sources of microorganisms. Some infectious bacteria were isolated from the dust associated carpets. Bacillus, Pseudomonas and Micrococcus were the dominated bacterial genera. The resuspension factor has an important role in the airborne bacterial load. Regular cleaning with antifungal and antibacterial-carpet shampoo and using disposable slippers may control numbers of microorganisms. It is recommended to study organic and inorganic compounds, especially during urban activity in the Holy Mosque. Integrated risk assessment of the indoor environment of the Holy Mosque should be studied in the future

\section{References}

Anderson, R., Mackel, D., Stoler, B., Mallison, G. (1982). Carpeting in hospitals an epidemiological evaluation. Journal of Clinical Microbiology, 15 (3): 408-415.

Aylor, D.E. (1976). Resuspension of particles from plant surfaces by wind. Proc of the atmosphere surface exchange of particulate and gaseous pollutants,
Richland WA, 4-6 Sept., 1974, pp 791-812, Energy Res and Rev., Admin. Symp. Ser, Conf-740921, National Technical Information Services, Springfield, VA.

Bholah, R. and Subratty, A. (2002). Indoor biological contaminants and symptoms of sick building syndrome in office buildings in Mauritius. Int. J Environ Health Res., 12 (1): 93-98.

Bouillard, L.; Michel, O.; Dramaix, M., Devleeschouwer, M. (2005). Bacterial contamination of indoor air, surfaces, and settled dust, and related dust endotoxin concentrations in healthy office buildings. Ann Agric Environ Med., 12:187-192.

Bowers, R.M., McCubbin, I.B., Hallar, A.G., Fierer, N. (2012). Seasonal variability in airborne bacterial communities at a high-elevation site. Atmos. Environ., 50: 41-49.

CRI, (2013). The carpet and rug institute. Antimicrobial carpet treatments, Technical Bulletin. https://www.carpetrug.org/Documents/Technical_Bulletins (Accessed 5 May, 2015).

Custovic, A., Murray, C.S.; Gore, R.B. et al. (2002). Controlling indoor allergens" Annals of Allergy, Asthma \& Immunology, 88: 432- 441 .

Dahdah, M.J. and Scher, R.K. (2008). Dermatophytes. Curr Fungal Infect Rep 2, 81-86.

Després, V., Alex Huffman, J., Burrows, S.M., Hoose, C., Safatov, A.S., Buryak, G., et al. (2012). Primary biological particles in the atmosphere: a review. Tellus, 64: 15598.

Dotterud, L.K., Vorland, L.H.; Falk, E.S. (1995). Viable fungi in indoor air in homes and schools in the SorVaranger community during winter. Pediatric Allergy and Immunology, 6: 181-186.

Ferro, A R.,. Kopperud, R. J.; Hildemann, L.M. (2004). Source strengths for indoor human activities that resuspend particulate matter. Environmental Science and Technology, 38 (6): 1759-1764.

Foarde, K. and Berry, M. (2004). Comparison of biocontaminant levels associated with hard vs. carpet floor in nonproblem schools: result ofv a year long study. J. Expo Anal Environ Epidemiol., 14 (1): S41-S48.

Gehring, U., Bischof, W., Fahlbusch, B., Wichmann, H.; Heinrich, J. (2002). House dust endotoxin and allergic sensitizationin children. Am. J Respir Crit Care Med., 166: 939-944.

Goksugur, N., Karabay, O.; Kocoglu, E. (2006). Mycological flora of the Hammams, traditional Turkish bath. Mycoses, 49: 411-414.

Gravesen, S., Larsen, L.; Skov, P. (1983). Aerobiology of schools and public institutions. Part of a study. Ecological Disorders, 2: 411-413. 
Hambraeus, A., Bengtsson, S.; Laurell, G. (1978). Bacterial contamination in a modern operating suite. 3 . Importance of floor contamination as a source of airborne bacteria. J. Hyg (Lond), 80:169-174.

Hansen, D.L. (1999). Indoor air quality issues. Taylor and Francie, 29 West 345th Street, NY 10001-2299, USA.

Hargreaves, M., Parappukkaran, S., Morawska, L., et al. (2003). A pilot investigation into associations between indoor airborne fungal and non-biological particle concentrations in residential houses in Brisbane, Australia. The Science of the Total Environment, 312: 89-101.

Harrison, R.M. and Perry, R. (1986). Handbook of air pollution analysis. 2nd ed., London, NY, Chapman and Hall.

Hassanien, M.A., Abdel Latif, N.M., Saleh, E.A.; Mohamed, A.M.F. (2009). Inhalation intake assessment of air pollutants exposure over Cairo, Egypt. In Exposure and Risk Assessment of chemical Pollution-Contemporary Methodology. (2009) Edited by L.I. Simeonov, and M.A. Hassanien, ISBN 978-90-481-2334-6, Springer.

Khan, A.A.H. and Karuppayil, S. M. (2012) Fungal pollution of indoor environments and its management. Saudi Journal of Biological Sciences; 19 (4): 405-426.

Katoh, T. (2006) Dermatomycosis and environment. Nihon Ishinkin Gakkai Zasshi, 47: 63-67.

Kembel, S.W., Cowan, P.D., Helmus, M.R., Cornwell, W.K., Morlon, H., Ackerly, D.D., Blomberg, S.P. and Webb, C.O. (2010) Picante: R tools for integrating phylogenies and ecology. Bioinformatics, 26: 1463-1464.

Leonas, K.K. (2003). Microorganisms in carpets, university of Georgia, http://www.carpetandrugpedia.com/PDF/Microorga nism \%20in\%20carpets.pdf.(Accessed on 5 May 2015).

Malik, Y., Allwood, P., Hedberg, C., Goyal, S. (2006) Disinfection of fabrics and carpets artificially contaminated with calicivirus: relevance in institutional and healthcare centres. Journal of Hospital Infection, 63:205-210.

Meckel, L. (1982) Carpeting and air pollution?. Schriftenr Ver Wasser Boden Lufthy, 53: 129-136.

Miller, D. and Colemans, S. (2015) Textile for residential and commercial interiors, 3rd ed. Bloomsbury Publishing Inc, Broadway, NY, NY 10018,USA, p. 410.
Nasrallah, M.M., Srouji, A.R. and Mashat, B.H. (2007) Study the internal climate, air quality and noise in the Holy Mosque. Report of the Custodian of the Two Holy Mosques Institute of the Hajj Research, Umm Al Qura University.

Nicholson, K.W. (1995) Physical aspects of bioaerosol sampling and deposition, In Cox CS and Wathes CM: Bioaerosols Handbook, p. 44, Lewis Publishers, Boco Raton, London.

Pope, A.M., Patterson, R.; Burg, H. (1993) Indoor allergens: assessing and controlling adverse health effects. The National Academy Press, Washington DC.

Raboobee, N., Aboobaker, J.; Peer, A.K. (1998) Tinea pedis et unguium in the Muslim community of Durban, South Africa. International Journal of Dermatology, 37: 759-765.

Ramachandran, G., Adgate, J., Banerjee, S., Church, T., Jones, D., Fredrickson, A.; Sexton, K. (2005) Indoor air quality in two urban elementary schools measurements of airborne fungi, carpet allergens, $\mathrm{CO} 2$, temperature, and relative humidity. Journal of Occupational and Environmental Hygiene, 2 (11): 553-566.

Rice, D., Hancock ,D., Roozen, P., Szymanski, M., Scheenstra, B.; Cady, K. (2003) Household contamination with Salmonella enterica. Emerg Infect Dis., 9:120 -122.

Rogers, J., Choi, Y., Richter, W., Rudnicki, D., Joseph, D., Sabourin, C., Taylor, M., Chang, J. (2007) Formaldehyde gas inactivation of Bacillus anthracis, Bacillus subtilis, and Geobacillus stearothermophilus spores on indoor surface materials. J Microbiol Methods, 103 (4): 1104-1112.

Sneath, P., Mair, N., Sharpe, M. and Holt, J. (2000) Bergey's Manual of Systematic Bacteriology, vol. 2, Williams \& Wilkins, Baltimore, Md, USA.

Stepalska, D., Harmato, K., Kasprzyk, I., Myszkowska, D. and Stach, A. (1999) Occurrence of airborne Cladosporium and Alternaria spores in southern and central Poland in 1995-1996. Aerobiologia, 15: 3947.

Sugimoto, R., Katoh, T., Nishioka, K. (1995) Isolation of dermatophytes from house dust on a medium containing gentamicin and flucytosine. Mycoses, 38 : $405-410$.

Yenisehirli, G., Karat, E., Bulut, Y. and Savci, U. (2012) Dermatophytes isolated from the mosques in Tokat, Turkey, Mycopathologia, 174: 327-330. 


\section{التلوث البكتيري والكيميائي المرتبط بغبار السجاد في المسجد الحرام بمكة المكرمة}

\section{بسام مشاط}

قسم البحوث البيئية والصحية، معطز خادم الحرين الثريفين لأبحاث الحج والعدرة، جامعة أم القرى، مكة المكرمة، المدلكة العربية السعودية

الكستخلص. بستخدم السجاد على نطاق واسع لتغطية الأسطح المختلفة في المسجد الحرام، وهو دائما ما يكون عرضة للتلوث الميكروبي والكيميائي. وتهدف هذه الدراسة إلى تقييم تركيزات البكتيريا والمركبات

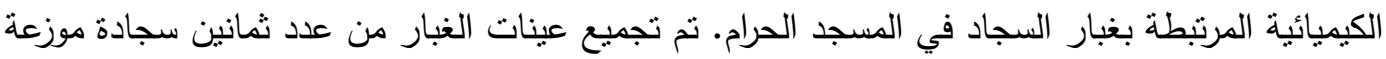

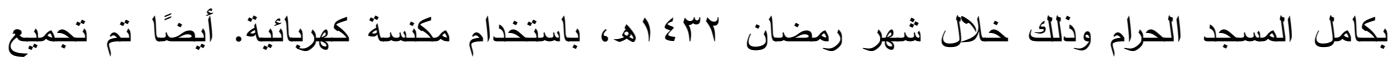
عينات البكتبريا المحمولة بالهواء باستخدام جهاز MD8 المحتوى على مرشح الجيلاتين. أظهرت النتائج

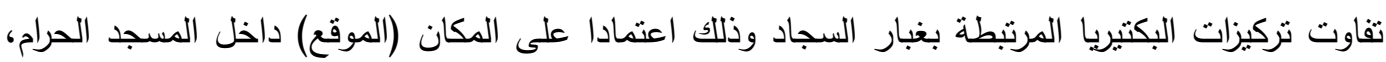

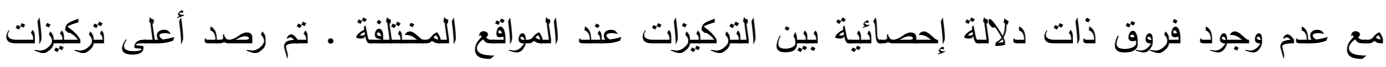

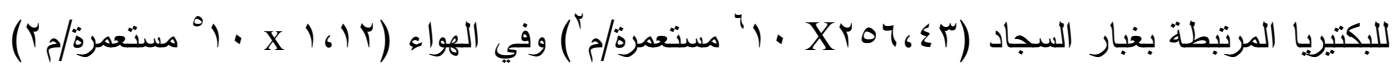

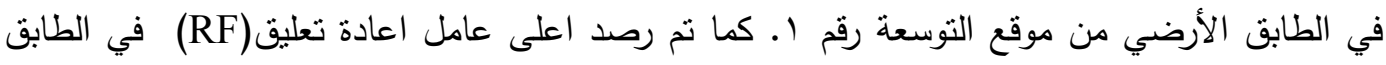

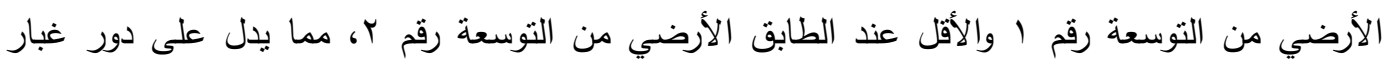

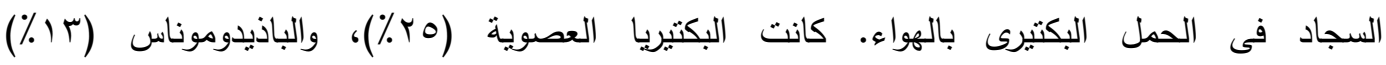

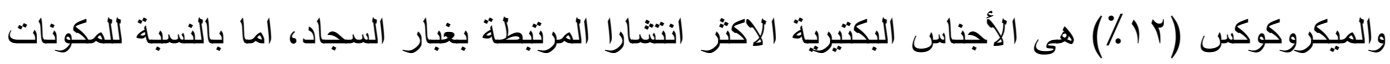

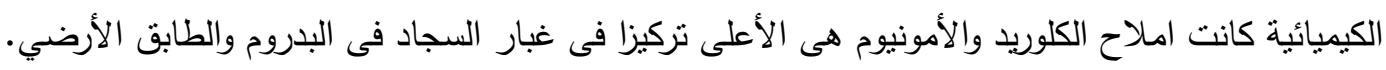

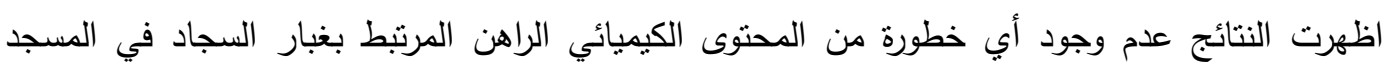

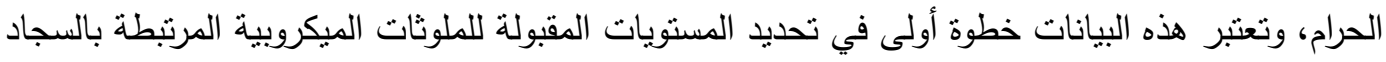

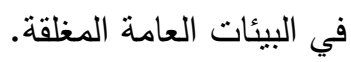
الكلمات الدالة: المسجد الحرام، السجاد، الأتربة، البكتبريا، النلوث الكيميائي، تقييم المخاطر. 
